\title{
LXII. On the fascinating power of snakes
}

\section{John Toplis A.M.}

To cite this article: John Toplis A.M. (1804) LXII. On the fascinating power of snakes, Philosophical Magazine Series 1, 19:76, 379-384, DOI: 10.1080/14786440408676582

To link to this article: http://dx.doi.org/10.1080/14786440408676582

$$
\text { 曲 Published online: } 18 \text { May } 2009 .
$$

Submit your article to this journal 전

Џ Article views: 2

Q View related articles $\sqsubset$ 
tion. We had already remarked that they seemed all to be on a level ; so that this observation indicates their common altitude at that moment. When we reached the earth there was no person near its to hold the balloon, and we were obliged to suffer all the gas to escape in order to stop it. Had we been able to foresee this disappointment, we should not have been anxious to descend so soon. About half after one. we found ourselves in the department of Loiret, near the village of Meriville, at the distance of about eighteen leagues from Paris.

We have not abandoned the design of rising to the height of 6000 metres, and even higher if possible, that we may continue our experiments on the compass at that elevation. We shall immediately prepare for this expedition, which will take place in the course of a few days, since the balloon has not sustained the smallest damage. M. GuyLussac will ascend first; and if he thinks it necessary, I will ascend alone in my turn to verify his observations. When we have terminated our experiments on the compass, we purpose undertaking several voyages together, to make exact researches, if possible, in regard to the nature and quantity of the electricity of the air at different heights, on the variations of the hygrometer, and on the diminution of heat as one removes from the earth,-all objects which must be useful in the theory of refraction.

We do not despair of being able also to observe angles, in order to determine trigonometrically our position in the heavens, which would give us some interesting ideas in regard to the movement of the barometer as one ascends. The motion of the balloon is so gentle that the nicest observations can be made in it; and the experience of our first journey, and in the use of our apparatus, will enable us in the course of a short time to collect a great number of facts. Such are our present intentions, should we be so fortunate as to find that the class consider our researches as of any utility.

LXII. On the fascinating Power of Snakes. By JoHN Toplis, A. M.*

\section{Mr.Tilloch,}

As the fascination attributed to many kinds of animals, particularly rattlesnakes, is a subject which has excited much inquiry and speculation, I hope the following attempt

* Communicated by the Author.

C c 4 
to elucidate what has caused so much astonishment and vague conjecture, may not prove unacceptable to the readers of your Magazine.

That various animals do possess the power of rendering others motionless and afterwards devouring them, is so well attested by individuals of different ages and conntries, that it is an unreasonable piece of scepticism to deny it. It appears to have been the belief of mankind at a very carly period, as it is mentioned by Homer, one of the oldest writers extant.

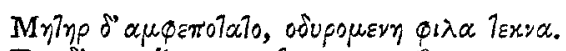

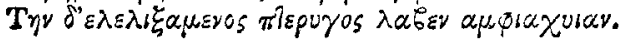

IL. B. 315 .

While hovering round with miserable moan,

The drooping mother wail' d her children gone :

The mother last, as round the nest she flew,

Seiz'd by the beating wing, the monster slew. Pope.

Toads, hawks, cats, owls, and various other animals, have been observed at times to possess the faculty of drawing towards them such small animals as serve them for food, by intently looking at them. That tigers have this power, is attested in the very entertaining account of the manner of hunting and sporting in Bengal, written by colonel Ironside, and inserted in the Philosophical Magazine, vol. xiv. p. 319 .

"It is somewhat extraordinary, but nevertheless a fact," says that writer, " the influence of fascination possessed by the tiger and all of his (the feline) species over many other creatures. Spied by deer particularly, they stop at once, as if struck by a spell; while the tiger lies still, his eyes fixed on them, and quietly awaiting their approach, which they seldom fail to make gradually within his spring; for the large royal tiger cannot run spcedily or far.

"Wherever tigers roam or couch, a number of birds continually hover or couch round about them, screaming or crying, as if to create an alarm. But the peacock seems to be particularly allured by him; for the instant a flock of peafowl perceive him they advance toward him directly, and fegin strutting round him with wings fluttering, quivering feathers, and bristling and expanded tails.

" Of this entiçement the fowlers also make their advantage; for, by painting a brown cloth screen, about six feet square, with black spots or streaks, and advancing under its cover fronting the sun, the birds either approach towards them, or suffer them to steal near enough to be sure of their mark by a hole left in the canvass for them to fire through. 
"Beyond all other animals, however, serpents possess most eminently this occult power: frequently are they seen revolving on the branches of trees or on the ground meditating their prey, - either birds, squirrels, rats, mice, bats, frogs, hares, or other animals."

Birds of prey, and particularly hawks, are frequently seen flying followed by numbers of those sorts of small birds upon which they are accustomed to feed. And I have been several times assured by different persons, whose veracity I have no reason to doubt, that if a man sees a hare sitting, and instantly fixes his eyes on its eyes, it will remain motionless until it be taken up by the hand.

M. Vaillant, in his New Travels into the Interior Parts of Africa, says, that the fascinating power of serpents is believed by the Hottentots as well as Negroes and Moors, That serpents have this fascinating property is attested by great numbers of travellers into various parts of the world and as it is asserted by the natives of very distant countries which have no communication with each other, there is the greatest reason to believe that it takes place. I shall not therefore trouble your readers with a long list of citations from various authors in confirmation of the fact, but content myself with relating the following instances for the information of those who may not be acquainted with its effects. They are all, but the last, extracted from the Gentleman's Magazine for the year 1765 , page 511 ; and were communicated by Mr. Peter Collison from a correspondent in Philadelphia.

"A person of good credit was travelling by the side of a creek or small river, where he saw a ground-squirrel moving to and fro between the creek and a great tree a few yards distant : the squirrel's hair looked very rough, which showed he was scared; and his returns being shorter and shorter, the man stood to observe the cause, and soon spied the head and neck of a rattlesnake pointing at the squirrel through a hole of the great tree, it being hollow : the squirrel at length gave over running, and laid himself quietly down with his head close to the snake's: the snake then opened his mouth wide and took in the squirrel's head; upon which the man gaye the snake a whip across the back, and so the squirrel being released he ran into the creek.

"6 When I was about thirteen years old, I lived with William Atkinson, an honest man, in Bucks county, who returning from a ride in warm weather, told us, that whilo his horse was drinking at a run, he heard the cry of a blackbird, which he espied on the top of a sapling, futtering and straining 
straining the way he seemed unwilling to fly, and holding so fast the sprigs he was perched upon, that the sapling top bent. After he had viewed the bird a few minutes, it quitted the place, and made a circle or two higher in the air, and then resumed its former standing, fluttering and crying. Thereupon William rode the way the bird strained, and soon spied a large black snake in coil, steadily eyeing the bird. He gave the snake a lash with his whip; and this taking of the snake's eye from his prey, the charm was broken, and away fled the bird, changing his note to a song of joy.

${ }_{66} \mathrm{Mr}$. Nicholas Scull, a surveyor, told me, that when he was a young man he happened once to be leaning upon a fence, and looking over it, he saw a large rattlesnake in coil looking stedfastly at him. He found himself surprised and listless immediately, and had no power for about a minute (as he thinks) but to look at the snake, and then he had the resolution to push himself from the fence and turn away feeling such horkor and confusion as he would not undergo again for any consideration.

" Dr. Chew tells me, a man in Maryland was found fault with by his companion that he did not come along: the companion stepping toward him, observed that his eyes were fixed upon a rattlesnake, which was gliding slowly towards him, with his head raised as if he was reaching up at him. The man was leaning towards the snake, and saying to himself, "He will bite me! he will bite me!" Upon which his companion caught him by the shoulder, pulled him about, and cried out, "What the devil ails you? He will bite you sure enough!' This man found himself very sick after his enchantment."

In addition to the above instances, I shall relate the following, which was told me by $\mathrm{Mr}$. Thomson, a gentleman who resided fourteen years at Burlinton, near Philadelphia, and in whose house $I$ now lodge. He says, that one day as he was fishing in a brook near Burlinton, he turned his head aside, and saw a very large black snake steadily eyeing him : from that moment all power of moving was taken from him; be stood motionless and filled with horror, unable to avoid the snake, which he saw approaching towards him. From this unpleasant situation he was removed by a dog which was with him; who coming up from a short distance, immediately saw the snake and flew at it. As soon as the snake turned from him to avoid the dog, he felt his powers yeturn; notwithstanding which he felt himself ill for some time after. 
A variety of hypotheses have been formed to account for this remarkable power; some supposing the animals to have een previously bitten, and from that cause unable to avoid their enemy; others, that the serpent emits from its body a stupefying vapour: it has been likewise asserted, that those birds that flutter round the mouth of the animal are in general those which nestle on the ground, in bushes, or on low trees, and which, having eggs or young: in their nests, expose their lives through love for their brood at the approach of their enemy. The most common opinion is that which is given in the Encyclopædia Britannica, article Serpent, viz. That the serpent is endued with an occult property of attracting small animals to it by its look, somewhat analogous to the attraction of iron by the magnet. The generality of philosophers, unable to account satisfactorily for this circumstance, and their minds revolting at the idea of admitting any occult or fascinating property in the animal, have peremptorily denied the fact. In opposition to the above opinions it has been observed, that the effect of the bite of a serpent is entirely different to that which attends fascination; and likewise, that if the serpent be disturbed the animal runs away uninjured. That it cannot arise from a stupefying vapour, is evident from birds living and enjoying themselves when put in a box with a rattlesnake. Fascination has likewise been observed to take place where no nest could be in the neighbourhood, and the bird at first at a considerable distance from the snake : besides, the same effect takes place with small quadrupeds.

It appears to me that this wonderful effect, which has been a matter of such astonishment, may be accounted for by attributing it to extreme fear. That this passion is sufficient to account for it, I shall attempt to prove; and if it appears to be so, where will be the necessity of admitting any occult or fascinating property in the snake? That extreme fear has the effect of rendering a person motionless is undoubted; there are few people who do not know instances of it: I could relate several, were it necessary. To what other cause can we attribute the fluttering of small birds in circles round hawks until they are seized and devoured, or the sudden fixed posture of a deer on the sight of a tiger? The fluttering of pea-fowls around it must arise from the same cause: nor can it be attributed to any peculiar property in the tiger, as one panted upon canvas is found to produce the same effect.

It is asserted by many (see Philosophical Magazine, vol, ii. page 253.) that the rattlesnake fascinates small birds 
and animals by means of its rattle; and they attribute tho whole charm to the terror produced by the sound of that organ. It is said moreover that the young Indians place a reed in their mouths, and imitate the noise made by the ratlesnake; by which means they are enabled to catch squirrels and small birds. By attributing the whole enchantment to fear, the above account will not seem improbable, as it is as easy to conceive that small hirds and squirrels may be stupefied by the terror arising from the known sound of the rattle, as from the sight of the serpent.

Could any doubt remain in the minds of my readers that fear is sufficient to account for the effect, I think the following extract from Drinkwater's Siege of Gibraltas will remove it. Speaking of the destruction occasioned by the falling of bomb-shells, he mentions the following remarkable circumstances: "In other cases in which the persons themselves bave observed the shot or shells coming towards them, they have been fascinated by its appearance, and unable to move from the spot, as small birds are said to be by the rattlesnake. This sudden arrest of the faculties was nothing uncommon : several instances occurred to my observation, where men totally free have had their senses so engaged by a shell in its descent, that though sensible of their danger, even so far as to cry for assistance, they have been immoveably fixed to their place. But what is more remarkable, these men have so instantaneously recovered themselves on its fall to the ground, as to remove to a place of safety before the shell burst. In this manner lieutenant Lowe of the 12th regiment was fascinated by a shot which he saw coming, but had not power to remove from the place before it fell upon him and took of his leg."*

As the sight of a ball or shell coming towards a man produces the same effect as the sight of a rattlesnake, why not attribute it to the same cause? In the case of a ball or shell the cause must be undoubtedly fear ; therefore we may conclude that the rattlesnake does not fascinate by any peculiar property inherent in it, but from the terror which it occasions by its approach,

Arnold, Notts, Yours, \&c.

September $7 x, 1804$.

JoHN TOPLIS. 